\title{
不整地歩行のための形状未知の地形に対する バネを有する点接触型足の着地制御法*
}

\author{
山田 萌 $* 1$, 真家 洋武 $* 2$, 佐野 滋則 $* 3$, 内山 直樹 $* 3$ \\ Landing Control of Point-Contact Type Foot with Springs \\ for Walking on Rough Terrain with Unknown Condition \\ Moyuru YAMADA*1, Hiromu MAIE, Shigenori SANO and Naoki UCHIYAMA \\ ${ }^{* 1}$ Graduate School of Mechanical and Structural System Engineering, Toyohashi University of Technology \\ 1-1, Hibarigaoka, Tenpaku, Toyohashi, Aichi, 441-8580, Japan
}

This paper presents a control method to achieve stable landing to rough and unknown terrain. Landing control is one of the important issues for biped walking robot, because robots are expected to walk on not only flat known surfaces but also unknown and uneven terrain to contribute to human society. A point-contact type foot with spring is employed in this control method, and it realizes stable contact with rough terrain and suppression of impact force. The proposed controller can adjust the foot position and posture without excessive impact by using the reaction force and torque estimated from the spring displacement, and guarantee the robust stability of control system with respect to terrain variance. The effectiveness of the proposed controller is demonstrated by experimental results.

Key Words : Landing Control, Rough Terrain, Point-Contact Type Foot

\section{1. 緒言}

2 足歩行は, 不整地への高い適応能力を有する移動形態であり, 階段のような既存のインフラを利用することが可 能である. このため, 2 足歩行ロボットは, 人間の生活環境において効果的に活動できる存在として期待され, 広く 研究されている. しかしながら, 現状では傾斜や凹凸, 曲面のある不整地における活動は困難であり, 不整地歩行の 実現か求められている(1) (3).

不整地歩行を実現するためには,以下に述べる地面と足との接地状態の不安定性および末知の地形への着地に関 する問題が解決されなくてはならない. 従来の平らな足の場合, 着地面が平らな整地においては,十分な広さの支持 多角形を比較的容易に得ることが可能である. しかし, 凹凸や曲面の存在する不整地においては, しばしば足の接触 状態が点接触や線接触となり, 十分な支持多角形を確保できずに転倒を引き起こす. また, 着地地面の複雑な 3 次元 形状をあらかじめ正確かつ即座に得ることは困難である. このため, 想定した着地位置と実際の位置との間に偏差 が生じ, 支持脚切換時の過度な衝撃や不完全な着地によりロボットの姿勢が不安定となる.

地面の凹凸や着地時の衝撃を吸収するため, ロボットの足底へゴム等の柔軟な緩衝材料を装着することが従来よ り広く行われてきた ${ }^{(4)(5)}$. しかしながら, この方法は, 微小な凹凸に対してのみ有効である. また, 過度に柔軟材料 を取り付けた場合, ロボットの安定性に悪影響を及ぼす可能性がある. このため, 橋本らはアクチュエータを備えた 足構造を提案し,セミアクティブな機構により地面の凹凸に足を適応させることで接地の安定化を試みている(6)(7). 足に取り付けられたアクチュエータによって,より積極的な地面への適応が可能となるが, この方法は重量増加を 招くと共にエネルギー効率を低下させる.

* 原稿受付 2011 年 2 月 18 日

*1 豊橋技術科学大学 大学院 機械・構造システム工学専攻 (广 441-8580 愛知県豊橋市天伯町雲雀ヶ丘1-1)

$* 2$ 豊橋技術科学大学

*3 正員, 豊橋技術科学大学 機械工学系

Email:sano@me.tut.ac.jp 

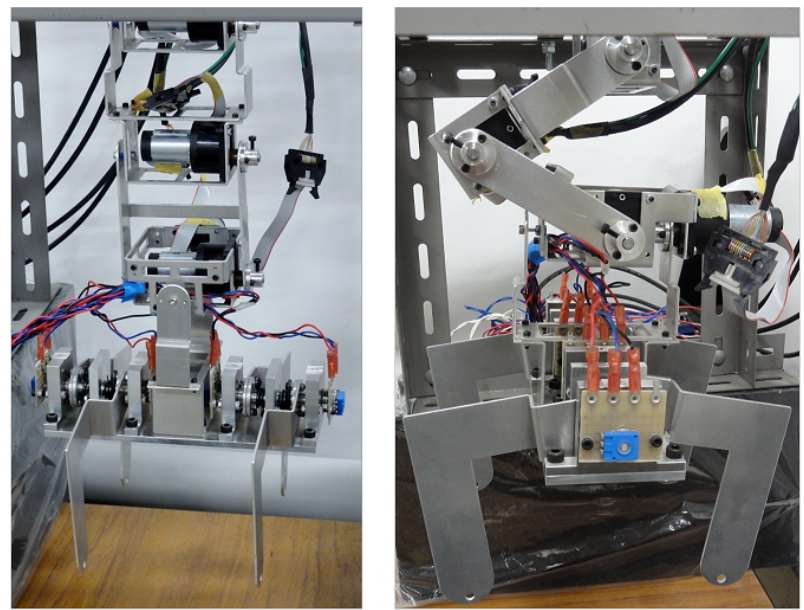

Fig. 1 Experimental system for landing control

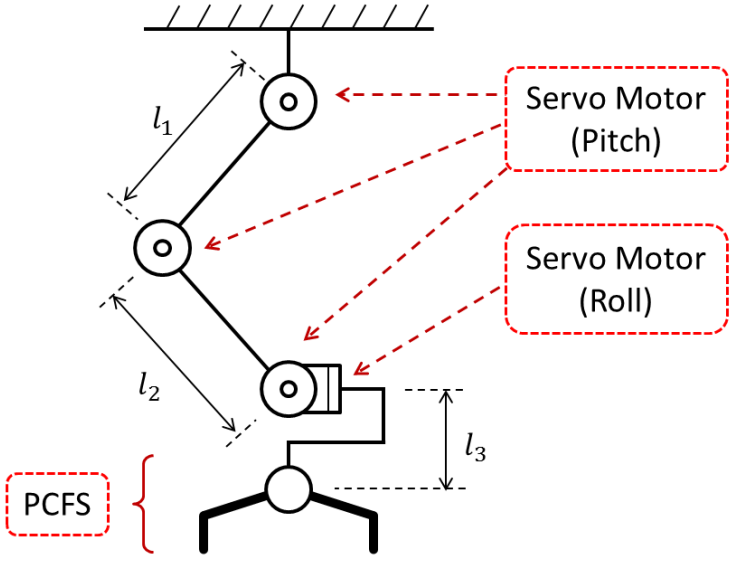

Fig. 2 Schematic of experimental system

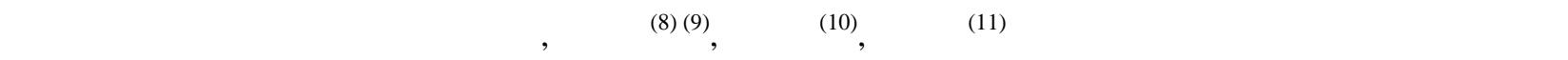
方法が提案されている. しかし, 床反力のフィードバック信号のみを用いて制御を行う場合, 着地時に生じるインパ ルス状の衝撃を抑えることは困難である. 一方, 各関節の角度制御ゲインの調整によってコンプライアンス制御を 実現する方法では, 衝撃緩和のため低ゲインとすることにより位置の制御性能が低下する. また, 着地地面か想定よ りも低い場合には, 別の方法によって対処しなければならない.ささらに, これらの制御法は, 制御性能や安定性につ いての理論的な議論が十分ではない.

筆者らは,バネを有する点接触型足 (PCFS : Point-Contact type Foot with Springs) を提案し, この PCFS を用いる ことにより, 不整地への柔軟な適応や安定接地, 着地時の衝撃や外力の吸収が可能であることを示した ${ }^{(12)}$. さらに, PCFS によるロボットの姿勢およびZMPの推定法を示すとともに, 対応可能な地形と姿勢の安定性を考慮した PCFS の設計法を提案した ${ }^{(13)}$. この設計法の有効性は, PCFS の試作機である PCFS-E1 により実験的に示された. また, 着 地時の衝撃抑制のためのバネとカセンサーを組み合わせた Sensor Unit, および高さ未知の地形に対するバネを有す る足の着地制御法を提案し, 光の有効性を実験により明らかにした ${ }^{(14)}$.さらに, この着地制御法と歩行パターンから なる歩行制御法を提案し, 動力学シミュレータ OpenHRP ${ }^{(15)(16)}$ を用いて, 高さ未知の段差が連続する地面における 有効性を明らかにするとともに, 従来困難であった環境下での安定歩行を単純な構造の 2 足ロボットで実現した ${ }^{(17)}$.

本論文では, 筆者らの提案した着地制御法 ${ }^{(14)}$ の対象を高さのみが未知の地形から傾きも未知な地形へ拡張する. 筆者らの従来の着地制御法は着地面が平らな場合にのみ有効であったが, 新たな提案法では未知の傾きが存在する 地面に対しても過大な反力やトルクを引き起こすことなく着地できる. さらに, PCFS と組み合わせることで, より 複雑な地形に対しても安定した着地と接地を実現できる. 以下では, まず本研究で対象とする実験装置について述 べる. 次に, 新たな着地モデルを提案し, 傾きも未知な地形に対する着地制御系の設計と光の安定性および制御性能 の解析を行う.最後に, 筆者らの開発した PCFS および新たに提案する着地法を組み合わせることで, 複雑な地形に 対しても安定した着地が可能であることを実験により示す.

\section{2. 実 験 装 置}

本章では, 研究の対象とする実験装置について述べる. 実験装置の外観および概略图を光れ光れ图 1 および図 2 に示す. 脚部は, 足先の高さと姿勢を任意に制御するため, Pitch 軸回りに 3 自由度, Roll 軸回りに 1 自由度, 全体で 4 自由度を有する. また, 各関節の角度は DC サーボモータによって制御される. 脚上部は固定され, 下部には筆者 らの開発したバネを有する点接触型足 (PCFS) が取り付けられている. 表 1 に各脚リンクの長さを示す. PCFS の 位置および Pitch, Roll 軸回りの姿勢については, 逆運動学を解くことによって各関節の目標角を算出し, これに追 従するようにモータ角をフィードバック制御することで制御できる.

脚の下部に取り付けられている PCFS(PCFS-E2 と呼ぶ) の外観を图 3 に示す. PCFS-E1 ではバネ要素としてねじ り棒を用いたが, 弾性範囲が狭いため, PCFS-E2 ではねじりバネに変更した. PCFS は, 地面と点接触する4つのリ ンクから構成され, 各リンクの回転部にバネとセンサが取り付けられている. また, (1) 地面と点接触することで複 


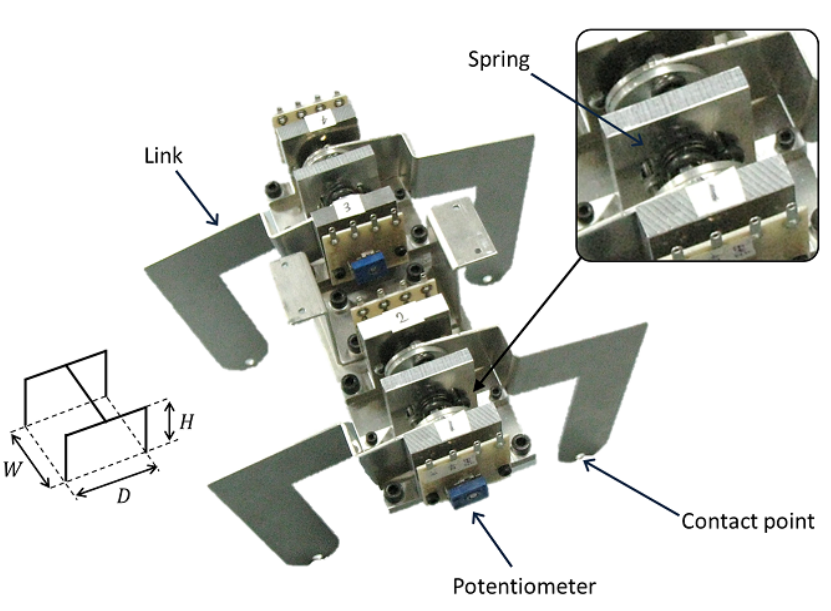

Fig. 3 PCFS-E2

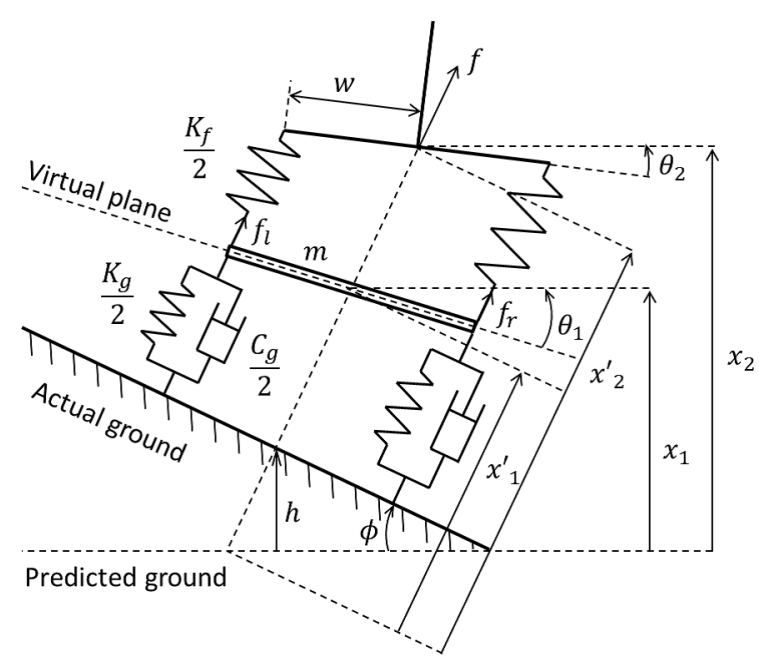

Fig. 4 Foot landing model

杂隹な不整地にも構造的に適応可能, (2) 高価な 6 軸力覚センサを用いることなく, ZMPや姿勢角などの安定性指標 か推定可能, (3) バネによって着地時の衝撃力を抑制可能, という利点を有する. 本研究で用いる PCFS-E2 の仕樣を 表 2 に示す. 足のフレームとリンクにアルミ材を用いている. 各回転バネのバネ定数は $4.1[\mathrm{Nm} / \mathrm{rad}]$ である. このバ ネ定数は, 質量 $4[\mathrm{Kg}]$ のロボットを想定し, PCFS の接触点間の高さが最大 $2.3[\mathrm{~cm}]$ 異なる地面に対し, 全接触点が 接地するように決定した. 詳細なバネ定数の設計法については, 文献 ${ }^{(13)}$ を参照されたい. 図 3 に示すように, PCFS の各リンクの関節には回転バネとポテンショメータを取り付けており, 乥れ独立にねじりバネの変位角を計測 できる. また, リンク $i(=1 \sim 4)$ の先端に加わる反力 $f_{i}$ は次式で求められる ${ }^{(13)}$.

$$
f_{i}=\frac{K_{\psi} d \psi_{i}}{r \sin \psi_{i}}
$$

ここで, $K_{\psi}$ は回転バネのバネ定数, $\psi_{i}$ は垂直軸からリンク $i$ までの角度, $d \psi_{i}$ は $i$ 番目のバネの変位角, $r$ は関節か ら接触点までの距離であり一定である.

\section{3. 制 御 系 設 計}

本章では, 形状が未知の地形への着地制御について述べる. このような地形への着地問題では, 過大な衝撃力と卜 ルクを抑制しつつ実際の地面への安定的な接地を実現しなくてはならない. すなわち, この着地制御には, 望ましい 反力およびトルク軌道への追従と足先の高さおよび姿勢の修正か赇められる. 本制御法は, PCFS のバネ変位より推 定した反カとトルクに基づき足首の位置と姿勢をリアルタイム制御し, 複雑な地面形状への安定した着地と接地を 実現する. 従来の平らな足では, このような凹凸面への安定接地や着地時の衝撃抑制は困難である.

まず, 高さおよび傾きが末知な地面への着地を取り扱うための数式モデルを構筑し,このモデルを対象として制 御系を設計する.つぎに, この制御系の安定性および制御性能の解析を行う.ここで述べる着地の安定性とは, 足が 受ける反力・トルクと足の高さ・傾きが発散しないことを意味する.

Table 1 Parameters of Experiment System

\begin{tabular}{ccc} 
Parameter & Value & Unit \\
\hline \hline$l_{1}$ & 0.091 & $\mathrm{~m}$ \\
\hline$l_{2}$ & 0.093 & $\mathrm{~m}$ \\
\hline$l_{3}$ & 0.086 & $\mathrm{~m}$ \\
\hline
\end{tabular}

Table 2 Parameters of PCFS-E2

\begin{tabular}{ccc} 
Parameter & Value & Unit \\
\hline \hline$W$ & 0.20 & $\mathrm{~m}$ \\
\hline$D$ & 0.21 & $\mathrm{~m}$ \\
\hline$H$ & 0.12 & $\mathrm{~m}$ \\
\hline Mass & 0.71 & $\mathrm{~kg}$ \\
\hline
\end{tabular}




\section{$3 \cdot 1$ 着地モデル}

想定している地面 (以下, 想定地面) と実際の地面 (実地面) に高さと傾きの偏差が存在する着地について考える. 制御系の設計および安定性の解析を行うため, 図 4 に示す PCFS の着地モデルを用いる. 图 4 では着地面が平らと なっているが, PCFS の場合は点接触であるから, 4 つの接触点からのずれが最小となる仮想平面 (Virtual plane) を 考えることで, 複雑な地形であっても本モデルを用いることができる. ここで, $m$ は PCFS の足先リンクの総質量, $w$ は足幅の半值, $C_{g}, K_{g}$ は地面と足の間の仮想的な粘性および弾性係数, $K_{f}$ は PCFS が有する 4 つの回転バネの弾 性係数の総和である. また, $x_{1}, x_{2}$ は仮想平面の中点 (足先の代表位置) と足のバネ上部の垂直位置, $x_{1}^{\prime}, x_{2}^{\prime}$ は実際の 地面に垂直な方向の位置である. $\theta_{1}, \theta_{2}$ は想定地面に対する仮想平面と足のバネ上部の傾き $h$ および $\phi$ は想定地面 と実地面との高さおよび傾きの偏差である. また, $f_{r}$ および $f_{l}$ は PCFS の前および後ろもしくは右側および左側の バネが受ける反力の総和, $f$ は足裏から受ける反力の総和である.

未知地形への着地において, 着地後の制御系の安定性が主問題となるため, ここでは着地後の状態について考え る. このモデルの運動方程式は次式で表される.

$$
\begin{aligned}
m \ddot{x}_{1}^{\prime} & =f_{l}+f_{r}-m g \cos \phi \\
I \ddot{\theta}_{1} & =\left(f_{l}-f_{r}\right) w \cos \left(\theta_{1}-\phi\right)
\end{aligned}
$$

さらに, $f_{l}, f_{r}$ は次式で表される.

$$
\begin{aligned}
f_{l}= & \frac{K_{g}}{2}\left(l_{1}-x^{\prime}{ }_{1}+h^{\prime}+d_{1}\right)-\frac{C_{g}}{2}\left(\dot{x}_{1}{ }_{1}-\dot{d}\right) \\
& -\frac{K_{f}}{2}\left(l_{2}-x^{\prime}{ }_{2}+x^{\prime}{ }_{1}-d_{1}+d_{2}\right) \\
f_{r}= & \frac{K_{g}}{2}\left(l_{1}-x_{1}^{\prime}{ }_{1}+h^{\prime}-d_{1}\right)-\frac{C_{g}}{2}\left(\dot{x}^{\prime}{ }_{1}+\dot{d}\right) \\
& -\frac{K_{f}}{2}\left(l_{2}-x^{\prime}{ }_{2}+x^{\prime}{ }_{1}+d_{1}-d_{2}\right)
\end{aligned}
$$

ここで, $l_{1}, l_{2}$ は光れ光れ地面と足との相互作用を表すバネと足に取り付けられているバネの自然長であり, $I$ は足 先リンクの慣性モーメント,$h^{\prime}=h / \cos \phi$ である. また $, d_{1}, d_{2}$ は傾きによる位置の微小变位であり次式で表される.

$$
\begin{aligned}
& d_{1}=w \sin \left(\phi-\theta_{1}\right) \\
& d_{2}=w \sin \left(\phi-\theta_{2}\right)
\end{aligned}
$$

式 (2), (3)へ式 (4)-(6) を代入し, $\phi-\theta_{1} \approx 0, \phi-\theta_{2} \approx 0$ とみなして線形化すれば次式が得られる.

$$
\begin{aligned}
& m \ddot{x}_{1}{ }_{1}+C_{g} \dot{x}_{1}{ }_{1}+\left(K_{g}+K_{f}\right) x_{1}^{\prime} \\
& =K_{f} x^{\prime}{ }_{2}-K_{f} l_{2}+K_{g}\left(l_{1}+h^{\prime}\right)-m g \cos \phi \\
& I \ddot{\theta}_{1}+C_{g} w^{2} \dot{\theta}_{1}+\left(K_{g}+K_{f}\right) w^{2} \theta_{1} \\
& =K_{f} w^{2} \theta_{2}+K_{g} w^{2} \phi
\end{aligned}
$$

次に, $h=0$ でかつ $\phi=0$ である理想的な場合について考える. このとき,式 (7), (8) より次の理想的な場合の運動 方程式が得られる.

$$
\begin{aligned}
& m \ddot{x}_{1 r e f}+C_{g} \dot{x}_{1 r e f}+\left(K_{g}+K_{f}\right) x_{1 r e f} \\
& =K_{f}\left(x_{2 r e f}-l_{2}\right)+K_{g} l_{1}-m g \\
& I \ddot{\theta}_{1 r e f}+C_{g} w^{2} \dot{\theta}_{1 r e f}+\left(K_{g}+K_{f}\right) w^{2} \theta_{1 r e f} \\
& =K_{f} w^{2} \theta_{2 r e f}
\end{aligned}
$$




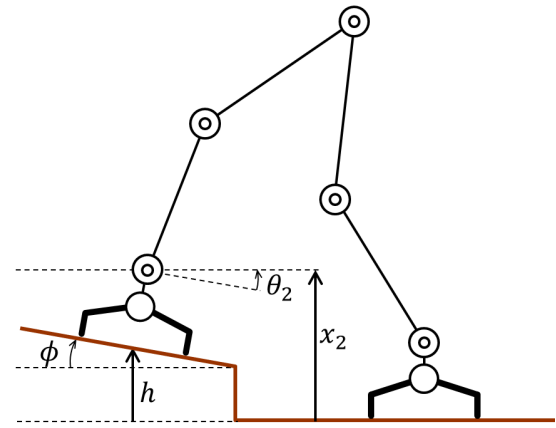

Fig. 5 Landing motion

ここで, 添え字の ref は理想的な值であることを意味する. 光して, 式 (9), (10) から式 (7), (8) を引くことにより, 次 の誤差方程式が得られる.

$$
\begin{aligned}
& m \Delta \ddot{x}_{1}+C_{g} \Delta \dot{x}_{1}+\left(K_{g}+K_{f}\right) \Delta x_{1} \\
& =K_{f} \Delta x_{2}-K_{g} \frac{h}{\cos \phi}-m g(1-\cos \phi) \\
& I \Delta \ddot{\theta}_{1}+C_{g} w^{2} \Delta \dot{\theta}_{1}+\left(K_{g}+K_{f}\right) w^{2} \Delta \theta_{1} \\
& =K_{f} w^{2} \Delta \theta_{2}-K_{g} w^{2} \phi
\end{aligned}
$$

ここで,

$$
\begin{aligned}
& \Delta x_{1}=x_{1 r e f}-x_{1}^{\prime}, \Delta x_{2}=x_{2 r e f}-x_{2}^{\prime} \\
& \Delta \theta_{1}=\theta_{1 \text { ref }}-\theta_{1}, \Delta \theta_{2}=\theta_{2 \text { ref }}-\theta_{2}
\end{aligned}
$$

なお, 以下では, $h, \phi$ および $K_{g}, C_{g}$ は未知であり,$f_{r}$ および $f_{l}$ はカセンサによって測定可能であると仮定する.

\section{$3 \cdot 2$ 制御入力}

本研究では, 図 5 に示すように, 足上部の位置 $x_{2}$ および姿勢 $\theta_{2}$ がアクチュエータにより任意に制御可能とし, こ れらを制御入力とみなす. 入力 $x_{2}$ および $\theta_{2}$ は, 一歩前の制御結果およびロボットの幾何学情報を用いて逆運動学 を解くことにより各関節の目標角度を算出し, これに追従するように各モータ角をフィードバック制御することで, 任意の位置と角度に制御できる.

本制御法の目的は, 地面からの反力およびトルクを理想的な值に追従させつつ足の位置と姿勢を実地面へならう

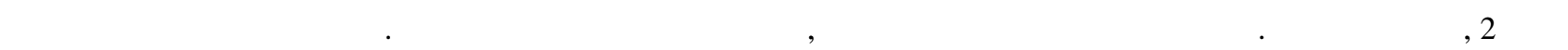
制御器から成り, 足の位置と姿勢を独立に制御する.

$$
\begin{aligned}
& x_{2}=x_{2 r e f}-K_{P x}\left(f_{r e f}-f\right)-K_{I x} \int_{0}^{t}\left(f_{r e f}-f\right) d \imath \\
& \theta_{2}=\theta_{2 r e f}-K_{P \theta}\left(\tau_{r e f}-\tau\right)-K_{I \theta} \int_{0}^{t}\left(\tau_{r e f}-\tau\right) d \imath
\end{aligned}
$$

ここで, $K_{P x}, K_{I x}, K_{P \theta}, K_{I \theta}$ は制御器ゲイン, $x_{2 r e f}, \theta_{2 r e f}$ は想定地面に対する足の位置および姿勢の目標軌道, $f_{r e f}, \tau_{r e f}$ は目標反力および目標卜ルク軌道であり, 想定地面へ理想的な着地をした場合の反力およびトルクに相当する. 軌 道 $x_{2 r e f}, \theta_{2 r e f}, f_{r e f}, \tau_{r e f}$ は与えられるものとする. また, これらの目標軌道を変えることで, 歩行ロボットで一般的な 足裏と地面が平行な着地や人間のように踵から着地するなどの樣々な着地動作を実現できる. 従来の硬く平らな足 では, このような柔軟な動作の指定および実現は困難である.

反力 $f_{r}$ および $f_{l}$ が測定可能であるから, $f$ および $\tau$ は次式より求めることができる.

$$
\begin{aligned}
& f=f_{l}+f_{r} \\
& \tau=w\left(f_{l}-f_{r}\right)
\end{aligned}
$$




\section{$3 \cdot 3$ 安定性解析}

本節では, 本研究で提案する制御系の安定性解析を行う.まず, 誤差方程式に制御入力を代入するため, 式 (14), (15) を変形する. 式 (14), (15) において, $f, \tau$ は次式で表される.

$$
\begin{aligned}
& f=K_{f}\left(l_{2}+x_{1}^{\prime}-x_{2}^{\prime}\right) \\
& \tau=K_{f} w^{2}\left(\theta_{1}-\theta_{2}\right)
\end{aligned}
$$

また,目標軌道に関しては次式が成立する.

$$
\begin{aligned}
f_{\text {ref }} & =K_{f}\left(l_{2}+x_{1 r e f}-x_{2 r e f}\right) \\
\tau_{r e f} & =K_{f} w^{2}\left(\theta_{1 r e f}-\theta_{2 r e f}\right)
\end{aligned}
$$

式 (17), (18) を制御入力式 (14), (15) に代入し次式を得る.

$$
\begin{aligned}
\Delta x_{2} & =\frac{K_{P x} K_{f} \Delta x_{1}+K_{I x} \int_{0}^{t} \Delta f d \imath-(1-\cos \phi) x_{2 r e f}}{\cos \phi+K_{P x} K_{f}} \\
\Delta \theta_{2} & =\frac{K_{P \theta} K_{f} w^{2} \Delta \theta_{1}+K_{I \theta} \int_{0}^{t} \Delta \tau d \imath}{1+K_{P \theta} K_{f} w^{2}}
\end{aligned}
$$

式(19)を式.(11),(12)に代入し整理すれば, 次式の状態空間表現を得る.

$$
\begin{aligned}
& \frac{d}{d t} \boldsymbol{x}=A \boldsymbol{x}+D \\
& \boldsymbol{x}=\left[\Delta \dot{x}_{1} \Delta x_{1} \int_{0}^{t} \Delta f d \imath\right]^{T} \\
& A=\left[\begin{array}{ccc}
-\frac{C_{g}}{m}-\frac{\left(K_{g}+K_{f}\right) \cos \phi+K_{P_{x}} K_{g} K_{f}}{m\left(\cos \phi+K_{P_{x}} K_{f}\right)} & \frac{K_{I X} K_{f}}{m\left(\cos \phi+K_{P_{x}} K_{f}\right)} \\
1 & 0 & 0 \\
0 & \frac{K_{f} \cos \phi}{\cos \phi+K_{P_{x}} K_{f}} & -\frac{K_{I X} K_{f}}{\cos \phi+K_{P_{x}} K_{f}}
\end{array}\right], D=\left[\begin{array}{c}
-\frac{K_{f}(1-\cos \phi)}{m\left(\cos \phi+K_{P_{x}} K_{f}\right)} x_{2 r e f}-\frac{K_{g}}{m} \frac{h}{\cos \phi}-g(1-\cos \phi) \\
0 \\
\frac{K_{f}(1-\cos \phi)}{\cos \phi+K_{P_{x}} K_{f}} x_{2 r e f}
\end{array}\right] \\
& \frac{d}{d t} \boldsymbol{\theta}=E \boldsymbol{\theta}+G \\
& \boldsymbol{\theta}=\left[\Delta \dot{\theta}_{1} \Delta \theta_{1} \int_{0}^{t} \Delta \tau d l\right]^{T}, E=\left[\begin{array}{ccc}
-\frac{C_{g} w^{2}}{I}-\frac{w^{2}\left(K_{g}+K_{f}+K_{P \theta} K_{g} K_{f} w^{2}\right)}{I\left(1+K_{P \theta} K_{f} w^{2}\right)} & \frac{K_{I \theta} K_{f} w^{2}}{I\left(1+K_{P \theta} K_{f} w^{2}\right)} \\
1 & 0 & 0 \\
0 & \frac{K_{f} w^{2}}{1+K_{P \theta} K_{f} w^{2}} & -\frac{K_{I \theta} K_{f} w^{2}}{1+K_{P \theta} K_{f} w^{2}}
\end{array}\right], G=\left[\begin{array}{c}
\frac{-K_{g} w^{2} \phi}{I} \\
0 \\
0
\end{array}\right]
\end{aligned}
$$

式 (20), (21) より足の位置および姿勢に関する特性方程式を求める. まず, 位置に関する特性方程式は, 式 (20)よ り次式となる.

$$
\begin{gathered}
s^{3}+\alpha_{1} s^{2}+\alpha_{2} s+\alpha_{3}=0 \\
\alpha_{1}=\left(\frac{C_{g}}{m}+\frac{K_{I x} K_{f}}{\cos \phi+K_{P x} K_{f}}\right), \alpha_{2}=\frac{\left(K_{g}+K_{f}\right) \cos \phi+K_{P x} K_{g} K_{f}+K_{P x} K_{f} C_{g}}{m\left(\cos \phi+K_{P_{x}} K_{f}\right)}, \alpha_{3}=\frac{K_{I x} K_{g} K_{f}}{m\left(\cos \phi+K_{P x} K_{f}\right)}
\end{gathered}
$$

姿勢に関する特性方程式は次式となる.

$$
s^{3}+\beta_{1} s^{2}+\beta_{2} s+\beta_{3}=0
$$




$$
\beta_{1}=\frac{C_{g} w^{2}}{I}+\frac{K_{I \theta} K_{f} w^{2}}{1+K_{P \theta} K_{f} w^{2}}, \beta_{2}=\frac{w^{2}\left\{K_{g}+K_{f}+w^{2}\left(K_{P \theta} K_{g} K_{f}+C_{g} K_{I \theta} K_{f}\right)\right\}}{I\left(1+K_{P \theta} K_{f} w^{2}\right)}, \beta_{3}=\frac{K_{I \theta} K_{g} K_{f} w^{4}}{I\left(1+K_{P \theta} K_{f} w^{2}\right)}
$$

これらの特性方程式は, ラウス・フルビッツの安定条件より次式が満たされれば安定であることが知られている.

$$
\begin{array}{r}
\alpha_{1}>0, \alpha_{2}>0, \alpha_{3}>0, \alpha_{1} \alpha_{2}-\alpha_{3}>0 \\
\beta_{1}>0, \beta_{2}>0, \beta_{3}>0, \beta_{1} \beta_{2}-\beta_{3}>0
\end{array}
$$

ここで, 地面の仮想弾性係数 $K_{g}$ 及び仮想粘性係数 $C_{g}$ は一般に正値をとるので, 全ての制御ゲインが正であれば, こ れらのパラメータによらずこの制御系は安定である. したがって, 提案法を用いることで,パラメータが末知の地面 に対しても安定な着地を実現できる. また, 地面の粘性係数 $C_{g}$ が 0 の場合にも安定となることが確認できる. これ は, 制御入力 (14), (15) において, 反力およびトルクの積分項が足の速度および角速度のフィードバックに対応する ためである. 一般にセンサ信号の微分には大きなノイズが含まれるが, 本制御法は, 反力やトルクの微分項がなくと も制御系を安定化できるため, 実装が容易である.

3.4 制御性能

本節では, 提案法により反力およびトルクが目標值へと収束することを示す. まず, 足位置および反力について検 証する. 式 (20) の左辺を 0 とすれば次式を得る.

$$
\begin{gathered}
a_{11} \Delta x_{1}+a_{12} \int_{0}^{t} \Delta f d \imath=a_{13} x_{2 r e f}+a_{14} \\
a_{11}=-\frac{\left(K_{g}+K_{f}\right) \cos \phi+K_{P x} K_{g} K_{f}}{m\left(\cos \phi+K_{P x} K_{f}\right)}, a_{12}=\frac{K_{I x} K_{f}}{m\left(\cos \phi+K_{P x} K_{f}\right)}, a_{13}=\frac{K_{f}(1-\cos \phi)}{m\left(\cos \phi+K_{P x} K_{f}\right)}, a_{14}=\frac{K_{g}}{m} \frac{h}{\cos \phi}-g(1-\cos \phi) \\
a_{21} \Delta x_{1}+a_{22} \int_{0}^{t} \Delta f d \imath=a_{23} x_{2 r e f} \\
a_{21}=\frac{K_{f} \cos \phi}{\cos \phi+K_{P x} K_{f}}, a_{22}=-\frac{K_{I x} K_{f}}{\cos \phi+K_{P x} K_{f}}, a_{23}=-\frac{K_{f}(1-\cos \phi)}{\cos \phi+K_{P x} K_{f}}
\end{gathered}
$$

式 (25), (26)より $x_{1}$ について解けば, 次式を得る.

$$
x_{1}=x_{1 r e f}+h-\frac{m g}{K_{g}}(1-\cos \phi) \cos \phi
$$

また, 式 (26) を時間微分することで, 反力誤差 $\Delta f$ の最終值は次式となる.

$$
\Delta f(\infty)=0
$$

式 (27) は, 未知の高さ偏差 $h$ に対応する修正量に加え足先リンクの自重による沈み込みによって偏差が生じるこ とを意味する. しかしながら, 地面の弾性係数は一般に非常に大きいため, 弚の偏差は微小であると考えられる. ま た, 式 (28)より, 反力が目標值に収束し, 本制御法の目的の 1 つが達成されることが分かる.

姿勢に関しても,式 (21) の左辺を 0 とし, $\theta_{1}$ について解けば,

$$
\theta_{1}=\theta_{1 r e f}+\phi
$$

また, 反力誤差の最終值を得たのと同樣の方法により, トルク誤差 $\Delta \tau$ の最終値に関して次式を得る.

$$
\Delta \tau(\infty)=0
$$

上式より, 足の姿勢か想定地面と実地面の傾き偏差 $\phi$ だけ修正された角度に収束することが分かる. また, トルク も目標值へと収束する.

以上より, 着地面の高さおよび傾きが末知な地形に対しても, 地面の特性パラメータによらず, 足の位置および姿 勢を修正しつつ足に加わる反カとトルクが目標值へと収束することか確認できた. 


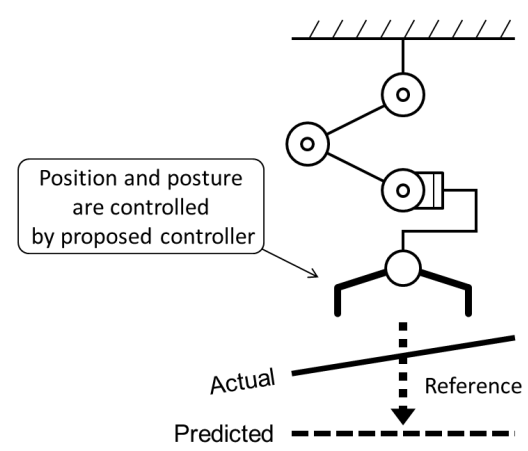

Fig. 6 Landing robot

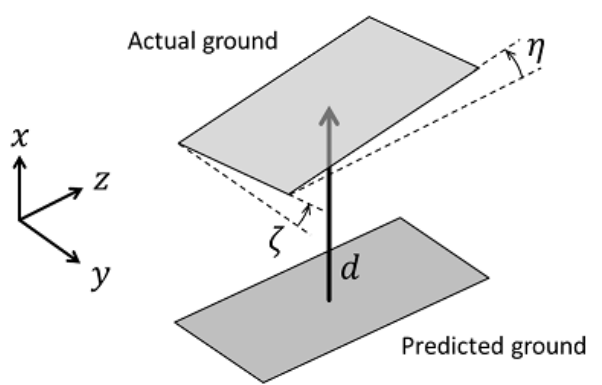

Fig. 7 Actual ground condition

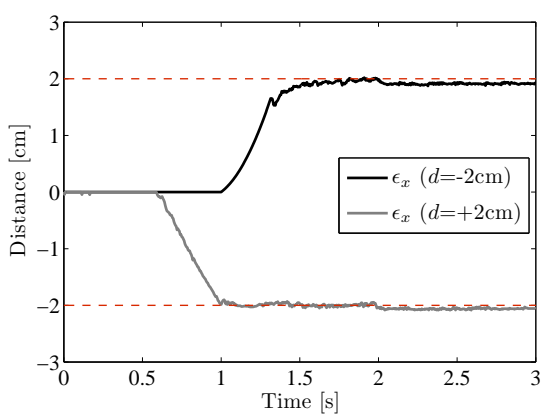

(a) Adjusted height

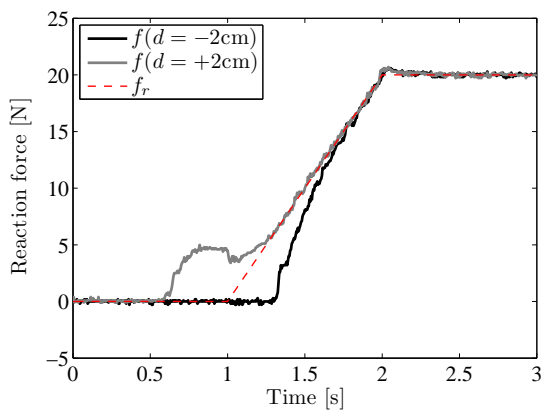

(b) Reaction force

Fig. 8 Control result $(d= \pm 2 \mathrm{~cm})$

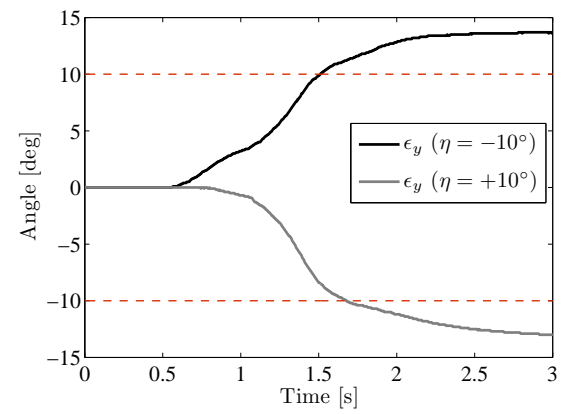

(a) Adjusted angle (y axis)

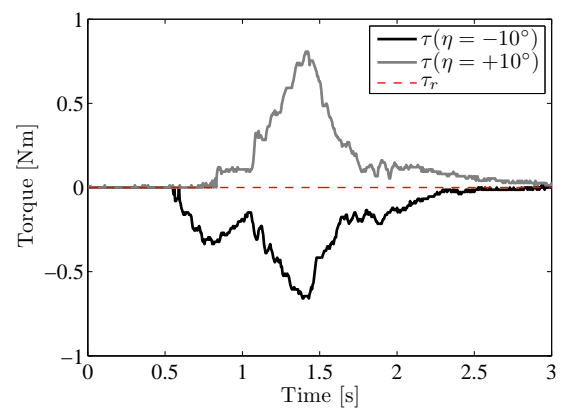

(b) Torque (y axis)

Fig. 9 Control result $\left(\eta= \pm 10^{\circ}\right)$

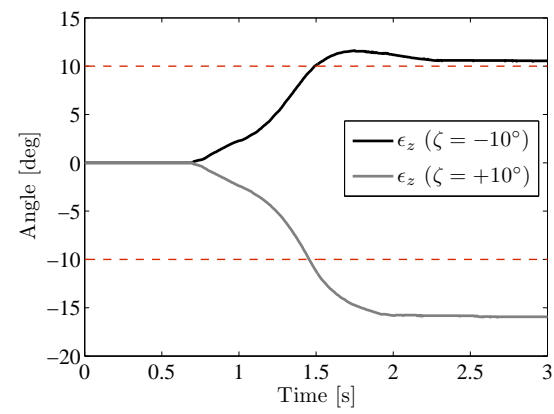

(a) Adjusted angle (z axis)

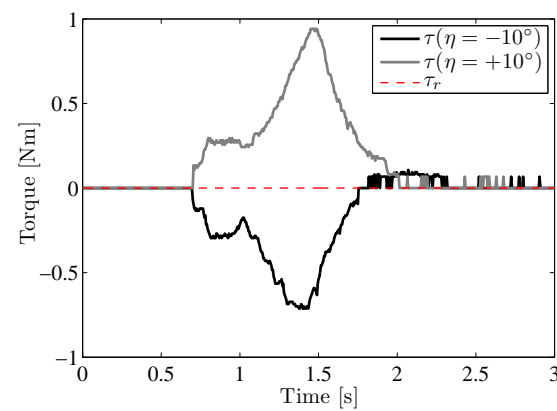

(b) Torque (z axis)

Fig. 10 Control result $\left(\zeta= \pm 10^{\circ}\right)$

\section{4. 着 地 実 験}

提案法の有効性を確認するため, 図 6 に示すように想定地面と実地面に偏差を与え, 着地実験を行った. 図 7 に示

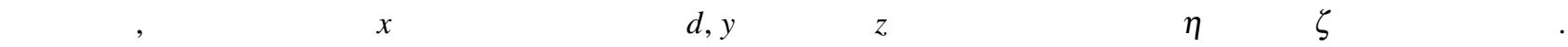
なお, $d$ は, 図 6 の Reference のように, 初期状態における足裏中心からの投影線上の距離とする.

PCFS の位置と傾きおよび反カとトルクの目標軌道として, 想定地面に対して理想的な着地をするための軌道を それ光れ以下のように与えた. 反力の目標軌道 $f_{r}$ は理想的な着地時間から線形的に増加し, 目標最大反力 $f_{r m a x}$ に 到達後一定値となるように設計した. $f_{r m a x}$ は, ロボットの重量を両足で均等に支えている状態において片足が受け る反力に相当するが, 本実験ではモータの性能を考慮し $20[\mathrm{~N}]$ とした. 想定着地時間および反力が着地から $f_{r m a x} に$ 達するまでの時間 $T$ は, どちらも $1[\mathrm{~s}]$ とした. 時間 $T$ は両足支持期の半分に相当するためより短く設定すべきで あるが, 実際の歩行では自重により自然と反力か増大するのに対し, 本実験では上端が固定されているため自ら足 を地面へ押し付ける必要がある. 光のため, モータの追従性能を考慮し, 上述の值に設定した. 足位置の目標軌道は 想定地面まで正弦波を用いて滑らかに移動し, 想定地面到達後は式 (17) を用いて目標反力を実現するような軌道 


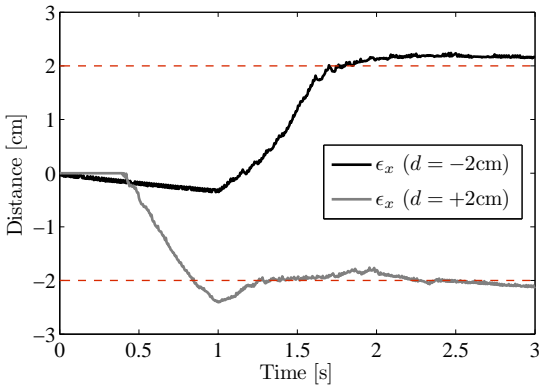

(a) Adjusted height

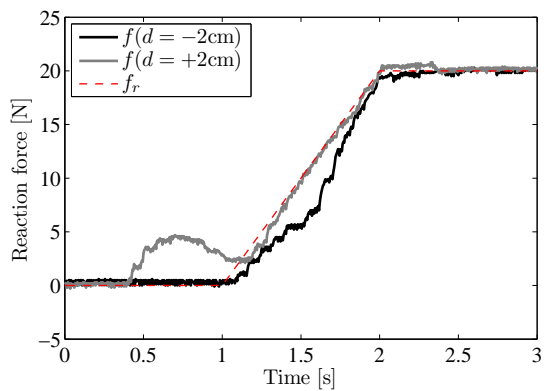

(b) Reaction force

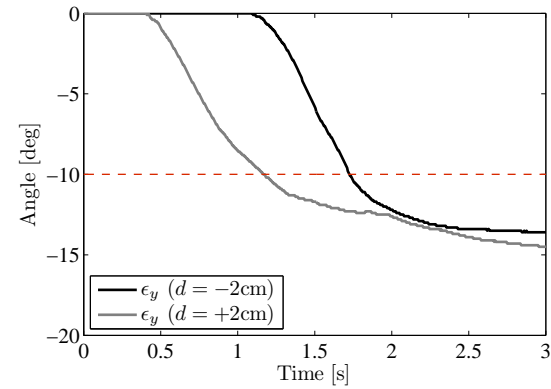

(c) Adjusted angle (y axis)

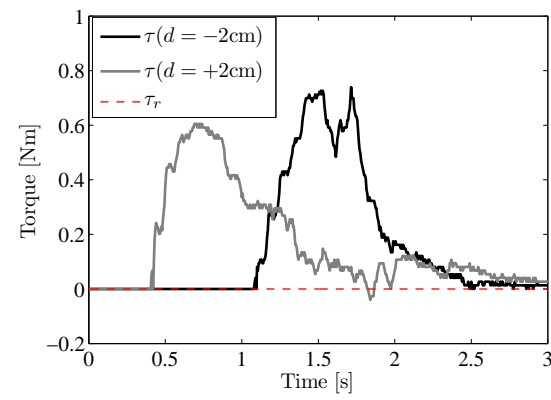

(d) Torque (y axis)

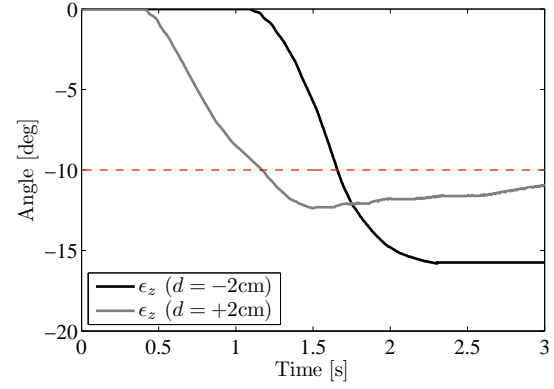

(e) Adjusted angle (z axis)

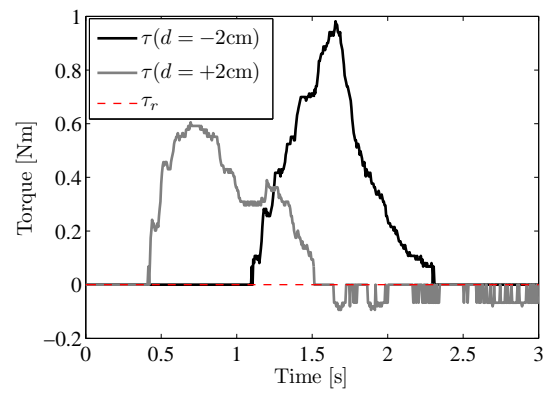

(f) Torque (z axis)

Fig. 11 Control result $\left(d= \pm 2 \mathrm{~cm}, \eta=10^{\circ}, \zeta=10^{\circ}\right)$

とした. トルクおよび姿勢の目標軌道は, 仮想平面 (図 4) と水平にするため常に 0 とした. 位置の制御ゲイン $K_{P x}$

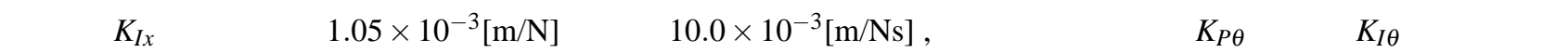
$0.0160[\mathrm{rad} / \mathrm{Nm}]$ および $0.520[\mathrm{rad} / \mathrm{Nms}]$ に設定した. これらのバネ定数は, PCFS-E2 の各回転バネのバネ定数を参考 に, 試行錯誤的に決定した. また, 制御と計測のサンプリング時間は $5[\mathrm{~ms}]$ とした.

図 8〜11 に想定地面と実地面の偏差を変化させたときの着地実験の結果を示す.ここで, 位置の修正量を $\varepsilon_{x}, \mathrm{y}$ 軸 および $\mathrm{z}$ 軸周りの修正角を光れ光れ $\varepsilon_{y}$ および $\varepsilon_{z}$ とした. まず, 図 8 は, 高さの偏差 $d$ のみを $\pm 2 \mathrm{~cm}$ 変化させた結果 である. この結果より, 過大な衝撃力を発生させることなく目標反力軌道に追従できていることが分かる. また, 実 地面が想定よりも高い場合と低い場合の双方において, 修正量が補うべき偏差の量へと収束している. 図 9 おび 図 10 は, $\mathrm{y}$ 軸または $\mathrm{z}$ 軸の偏差を $\pm 10^{\circ}$ 変化させたときの結果である. いずれの軸についてもトルクが目標值へと 収束している. 角度の修正量は, 理論值との間に偏差があるが, 安定的に収束している. この偏差は, 実験装置の設定 誤差とモータのバックラッシの影響であると考えられる. 今回の実験で使用したモータは公称で無負荷時に 2 度程 度のバックラッシが存在しており, 乥の影響が大きい. しかしながら, 足が受けるトルクは良好に制御できており, また, 目視によって着地後の足が実地面と平行であることを確認した. 図 11 は, $\mathrm{y}$ と $\mathrm{z}$ の両軸に一定の傾きの偏差 $+10^{\circ}$ を元, さらに高さ偏差を $\pm 2 \mathrm{~cm}$ 変化させたときの結果である. この結果から分かるように, 実地面か想定地 面と大きく異なる場合においても, 反力およびトルクは目標值へと良好に収束しており, 実地面への安定した着地 か実現されている.

\section{5. 結言}

本研究では, 高さおよび傾きが未知の不整地への安定的な着地を目的とし, バネを有する点接触型足を用いた着 地制御法を提案した. また, 2 次元着地モデルを用いて, この制御法の安定性および制御性能について解析した. 本 制御法は, 足の各接触点に加わる力から反力とトルクを推定し, これらの情報を用いて足の位置と姿勢を修正する ことで, 想定と異なる高さや傾きの地面に対しても滑らかな着地を実現できる. また, 地面の特性パラメータの変動 に対するロバスト性を有し, 反力計測値の微分情報を必要としないため実装が容易という特徵を持つ. 着地実験に よりこの提案法の有効性を確認した. 提案する足では接触点における反力をリアルタイム計測できるため, これを 利用した不整地での滑らかな歩行動作の実現が期待でき,今後の研究課題である . 
謝 辞

本研究にご支援いただいた財団法人堀科学芸術振興財団に対し御礼申し上げます.

文献

(1) 庄司 道彦, 王志東, 高橋 隆行, 中野 栄二,“ 二脚ロボットの佇立能力向上のための足構造”, バイオメカニズム学会誌, Vol. 25, No. 1 (2001), pp. 36-42.

(2) 梶田 秀司, 谷 和男,“実時間路面形状測定に基づく動的 2 足歩行の制御”, 日本ロボット学会誌, Vol. 14, No. 7 (1996), pp. 1062-1069.

(3) 梶田 秀司, 谷 和男,“線形倒立振子モードを規範とする凹凸路面上の動的 2 足歩行制御”, 計測自動制御学会論文集, Vol. 31, No. 10 (1995), pp.1705-1714.

(4) Kaneko, K., Kanehiro, F., Kajita, S., Hirukawa, H., Kawasaki, T., Hirata, M., Akachi, K., and Isozumi, T, "Humanoid Robot HRP-2", Proc. 2004 IEEE Int. Conf. on Robotics and automation, Vol. 2 (2004), pp. 1083-1090

(5) 山口 仁一, 木下 昇, 高西 淳夫, 加藤一郎,“路面形状に偏差のある環境に対する適応能力を持つ 2 足歩行ロボットの開発”, 日本ロボット学会誌, Vol. 14, No. 4 (1996), pp. 546-559.

(6) Hashimoto, K., Sugahara, Y., Hayashi, A., Kawase, M., Sawato, T., Endo, N., Ohta, A., Tanaka, C., and Takanishi, A., “New Foot System Adaptable to Convex and Concave Surface", Proc. 2007 IEEE Int. Conf. on Robotics and Automation, (2007), pp. 1869-1874.

(7) 橋本健二, 菅原雄介, 太田章博, 砂塚裕之, 川瀬正幹,“ 2 足歩行ロボットの不整地適応能力向上を図った足部機構の開発 (第 2 報 : 保持機構の強化による不整地歩行の実現) ”, 第 23 回日本ロボット学会学術講演, (2005), 1G23.

（8）橋本 健二, 菅原 雄介, 川瀬 正幹, 林 昭宏, 田中 智明, 太田 章博, 沢戶 瑛昌, 遠藤 信綱, 林 憲玉, 高西 淳夫, “着地軌道修正制 御と推定姿勢補償制御による人間搭乗型 2 足歩行ロボットの屋外歩行の実現”, 日本ロボット学会誌, Vol. 25, No. 6 (2007), pp.851-859.

（9）橋本 健二, 菅原 雄介, 砂塚 裕之, 田中 智明, 太田 章博, 川瀬 正幹, 林 憲玉, 高西 淳夫, “脚部にパラレルリンク機構 を用いた 2 足ロコモータの開発（第 9 報 : 非線形コンプライアンス制御を用いた着地軌道修正法と不整地歩行の実現)”， 第 23 回日本ロボット学会学術講演会, (2005), $1 \mathrm{G} 26$.

(10) 中野栄二, 小森谷清, 米田完, 高橋隆行,“高知能移動ロボティクス”, 講談社, (2004), pp.153-170.

(11) 中嶋 秀朗, 中野 栄二,“脚車輪分離型ロボットの大不整地適応歩容 (第 2 報, 段差上り歩容編)”, 日本機械学会論文集 (C 編), Vol. 72, No. 721 (2006), pp. 2932-2939.

(12) Sano, S., Yamada, M., Uchiyama, N., and Takagi, S, "Point-Contact Type Foot with Springs and Posture Control for Biped Walking on Rough Terrain", Proc. IEEE Int. Workshop on Advanced Motion Control, (2008), pp. 480-485.

(13) Yamada, M., Maie, H., Maeno, Y., Sano, S., and Uchiyama, N., "Design of Point-Contact Type Foot with Springs for Biped Robot”, Proc. 2010 IEEE/ASME Int. Conf. on Advanced Intelligent Mechatronics, (2010), pp. 806-811.

(14) 山田 萌, 佐野 滋則, 内山 直樹, 高木 章二,“不整地歩行のための高さ未知の地形に対するバネを有する足の着地制御法”, 日本ロボット学会誌, Vol. 28, No.9 (2010), pp. 79-85.

(15) Hirukawa, H., Hattori, S., Kajita, S., Harada, K., Kaneko, K., Kanehiro, F., Morisawa, M., and Nakaoka, S, “A Pattern Generator of Humanoid Robots Walking on a Rough Terrain”, Proc. 2007 IEEE Int. Conf. on Robotics and Automation, (2007), pp. 21812187.

(16) Morisawa, M., Harada, K., Kajita, S., Kaneko, K., Kanehiro, F., Fujiwara, K., Nakaoka, S., Hirukawa, H., "A Biped Pattern Generation Allowing Immediate Modification of Foot Placement in Real-time", Proc. IEEE-RAS Int. Conf. on Humanoid Robots, (2006), pp. 581-5862.

(17) Yamada, M., Sano, S., and Uchiyama, N., "Walking control on unknown and uneven terrain for biped robot with spring embedded feet", Proc. 13th Int. Conf. on Climbing and Walking Robots and the Support Technologies for Mobile Machines, (2010), pp. 557562. 